\title{
Graves' ophthalmopathy and tongue cancer complicated by peg-interferon $\alpha-2 b$ and ribavirin therapy for chronic hepatitis C: A case report and review of the literature
}

\author{
YUMIKO NAGAO $^{1}$, YUJI HIROMATSU ${ }^{2}$, TADASHI NAKASHIMA ${ }^{3}$ and MICHIO SATA ${ }^{1,4}$ \\ ${ }^{1}$ Department of Digestive Disease Information and Research, ${ }^{2}$ Division of Endocrinology and Metabolism, \\ Department of Medicine, ${ }^{3}$ Department of Otolaryngology, ${ }^{4}$ Division of Gastroenterology, Department of Medicine, \\ Kurume University School of Medicine, Asahi-machi, Kurume, Fukuoka 830-0011, Japan
}

Received May 30, 2008; Accepted July 17, 2008

DOI: 10.3892/mmr_00000003

\begin{abstract}
Hepatitis C virus (HCV) infection induces not only chronic liver disease, but also extrahepatic manifestations such as thyroid disease and oral cancer. Thyroid dysfunction is also a complication known to be associated with interferon (IFN) therapy for HCV infection. We report on a 69-year-old Japanese man who developed Graves' ophthalmopathy and tongue cancer (malignant transformation of leukoplakia) while receiving peg-interferon (Peg-IFN) $\alpha-2 b$ and ribavirin (RBV) treatment for chronic hepatitis $\mathrm{C}$. This patient had no history of thyroid disease before the combination therapy, but did have bilateral leukoplakia of the tongue. The leukoplakia lesions did not change until 20 weeks after the start of the combination therapy, and ophthalmopathy was not diagnosed until 47 weeks later. As ophthalmopathy is considered to be a severe adverse event induced by Peg-IFN $\alpha-2 b$ plus RBV, therapy was discontinued after 47 weeks. The patient received a partial glossectomy to remove the malignant neoplasm as well as
\end{abstract}

Correspondence to: Dr Yumiko Nagao, Department of Digestive Disease Information and Research, Kurume University School of Medicine, 67 Asahi-machi, Kurume 830-0011, Japan

E-mail:nagao@med.kurume-u.ac.jp

Abbreviations: $\mathrm{HCV}$, hepatitis C virus; IFN, interferon; Peg-IFN, peg-interferon; RBV, ribavirin; HCC, hepatocellular carcinoma; MRI, magnetic resonance imaging; $\mathrm{HBsAg}$, hepatitis B surface antigen; $\mathrm{TSH}$, thyroid stimulating hormone; $\mathrm{FT}_{3}$, free tri-iodothyronine; $\mathrm{FT}_{4}$, free thyroxine; TPOAb, thyroid peroxidase antibodies; $\mathrm{TgAb}$, thyroglobulin antibodies; anti-HCV, HCV antibody; RBC, red blood cell; Hb, hemoglobin; WBC, white blood cell; AST, aspartate aminotransferase; ALT, alanine aminotransferase; $\gamma$-GTP, $\gamma$-glutamyl transpeptidase; LDH, lactate dehydrogenase; TRAb, TSH receptor antibody; TSAb, thyroid stimulating antibody; hTRAb, human TSH receptor antibody

Key words: hepatitis C virus, peg-interferon, ribavirin, Graves' ophthalmopathy, extrahepatic manifestation, oral squamous cell carcinoma extraocular muscle surgery for the ophthalmopathy, and was treated with an antithyroid agent and steroids. In conclusion, it is necessary to clinically examine organs other than the liver in patients with $\mathrm{HCV}$ infection.

\section{Introduction}

Hepatitis $\mathrm{C}$ virus (HCV) frequently causes persistent infection, which leads to chronic liver disease and hepatocellular carcinoma (HCC). HCV-related HCC represents $80 \%$ of all HCC cases in Japan (1) and primary liver cancer, 95\% of which is HCC-related, ranks third in men and fifth in women as the cause of death from malignant neoplasms. Interferon (IFN) $\alpha$ monotherapy for chronic hepatitis $\mathrm{C}$ infection leads to a sustained virological response in only $10-15 \%$ of HCVinfected patients $(2,3)$. A substantial improvement in response of approximately 2 -fold over IFN monotherapy was noted using the combination of IFN $\alpha$ plus ribavirin (RBV) $(4,5)$. Recently, a combination treatment of peg-interferon (Peg-IFN) plus RBV has been adopted as standard care for patients with chronic hepatitis $\mathrm{C}$, as it is associated with significant improvements in the rate of sustained virological response $(50 \%)$ as compared to IFN $\alpha$ plus RBV or Peg-IFN $\alpha$ alone (6).

$\mathrm{HCV}$ infection has also been associated with extrahepatic manifestations and immune-mediated phenomena (7), including mixed cryoglobulinemia (8), thyroid disease (9), Sjögren's syndrome (10), porphyria cutanea tarda (11), lichen planus (12), oral cancer $(13,14)$ and type 2 diabetes mellitus $(15)$. The incidence of $\mathrm{HCV}$ infection in oral squamous cell carcinoma in Japanese patients has been reported as being $16.7-24.0 \%$ $(13,14)$.

The side effects of IFN therapy for HCV have been well documented $(16,17)$. Flu-like symptoms such as fever, chills, muscle ache, nausea, vomiting and fatigue are common side effects of treatment. Depression and related symptoms, such as anxiety, irritability, insomnia and mental confusion, are not rare and, in patients with a previous history, may be significant. Withdrawal rates in IFN-based combination studies due to side effects have ranged from 6 to $7 \%$ (5). Various side effects have been reported in patients treated with this cytokine, including the appearance or exacerbation 
of underlying autoimmune diseases and the development of a variety of organ- and non-organ-specific autoantibodies (18). Auto-immune thyroid disease is a common side effect of IFN treatment of viral hepatitis C, affecting 2-19\% of IFN-treated patients (19). We previously reported the case of a patient with chronic hepatitis $\mathrm{C}$ who developed worsening lichen planus lesions during treatment with IFN plus RBV (20), and the case of a patient who developed oral cancer after IFN therapy (21).

We now describe a patient with chronic hepatitis $C$ infection who developed hyperthyroidism, Graves' ophthalmopathy and malignant transformation of tongue leukoplakia during combination therapy with Peg-IFN $\alpha-2 b$ and RBV. This patient was treated successfully.

\section{Case report}

A 67-year-old Japanese man, diagnosed in 1998 with chronic hepatitis C, consulted the Digestive Disease Center of Kurume University on June 6, 2003 for treatment of his chronic liver disease. The patient had received a right upper lobectomy for lung tuberculosis at the age of 23 (in 1958), and had been administered blood transfusions of $600 \mathrm{ml}$ during the procedure. Hypertension was noted at the age of 67, and antihypertensive treatment was started at 68 . Hemangioma of the right middle finger was diagnosed at 69 . For 20 years, he smoked 50 cigarettes a day, though he had not smoked for the last 30 years. His alcohol consumption was $500 \mathrm{ml}$ of beer daily for 49 years. His family history was non-contributory.

Periodic blood tests and abdominal ultrasound exams were conducted by a hepatologist at Kurume University. As the patient's aminotransferase levels were in the normal range, he was monitored regularly for chronic hepatitis C. On July 30, 2004 , at the age of 69 , his aminotransferase levels were found to be elevated and a liver biopsy revealed chronic active hepatitis, diagnosed as F2A2 according to the new Inuyama classification (22). As of June 14, 2005, for a period of 1-3 months, the patient was treated by a family doctor with a combination of peg-IFN $\alpha$-2b (Peg-Intron ${ }^{\circledR}$; Schering-Plough, Kenilworth, NJ, USA) (40-100 $\mu \mathrm{g} /$ week) plus RBV (Rebetol ${ }^{\circledR}$; Schering-Plough) (300-800 mg/day). During this time, he was examined by a hepatologist once.

At the start of Peg-IFN $\alpha$-2b plus RBV therapy, laboratory data regarding hepatitis virus markers indicated that the patient was negative for hepatitis B surface antigen (HBsAg), but positive for HCV antibody (anti-HCV) and HCV RNA. Both free thyroxine $\left(\mathrm{FT}_{4}\right)$ and thyroid stimulating hormone (TSH) levels before Peg-IFN plus RBA therapy were within normal ranges (Table I).

In March 2006, while undergoing Peg-IFN plus RBV therapy, the patient experienced double vision. He did not consult a family doctor or a hepatologist, but was examined by an ophthalmologist, and then by a neurosurgeon who prescribed magnetic resonance imaging (MRI) followed by a neurological examination at Kurume University Hospital on May 9, 2006. Thyroid function tests on February 10, 2006 revealed suppressed $\mathrm{TSH}$ at $0.016 \mu \mathrm{IU} / \mathrm{ml}$ (normal value 0.21-3.85) and elevated free tri-iodothyronine $\left(\mathrm{FT}_{3}\right)$ at $4.1 \mathrm{pg} /$ $\mathrm{ml}$ (normal value 1.9-3.5), but the hepatologist did not diagnose thyroid disease. Over the next 3 months, thyroid function tests revealed hyperthyroidism of autoimmune etiology, indi-
Table I. Laboratory data of patient with hepatitis $C$ virus infection at the time of admission for Peg-IFN and RBV therapy.

\begin{tabular}{|c|c|c|c|}
\hline Laboratory assay & Value & Unit & Standard value \\
\hline $\mathrm{RBC}$ & 483 & $\mathrm{x} 10^{4} / \mathrm{mm}^{3}$ & $430-570$ \\
\hline $\mathrm{Hb}$ & 16.0 & $\mathrm{~g} / \mathrm{dl}$ & $14.0-18.0$ \\
\hline $\mathrm{Ht}$ & 46.9 & $\%$ & $40.0-52.0$ \\
\hline WBC & 63 & $\mathrm{x} 10^{4} / \mathrm{mm}^{3}$ & $40-90$ \\
\hline Plt & 17.4 & $\mathrm{x} 10^{4} / \mathrm{mm}^{3}$ & $13.0-36.0$ \\
\hline $\mathrm{AST}$ & 32 & $\mathrm{U} / 1$ & 13-33 \\
\hline ALT & 32 & $\mathrm{U} / 1$ & $8-42$ \\
\hline $\mathrm{LDH}$ & 170 & $\mathrm{U} / 1$ & $119-229$ \\
\hline ALP & 209 & $\mathrm{U} / 1$ & $115-359$ \\
\hline$\gamma$-GTP & $\underline{90}$ & $\mathrm{U} / 1$ & $10-47$ \\
\hline $\mathrm{TP}$ & 7.21 & $\mathrm{~g} / \mathrm{dl}$ & $6.70-8.30$ \\
\hline Alb & 4.11 & $\mathrm{~g} / \mathrm{dl}$ & $4.00-5.00$ \\
\hline $\mathrm{ChE}$ & 160 & IU/1 & $107-233$ \\
\hline $\mathrm{TC}$ & 140 & $\mathrm{mg} / \mathrm{dl}$ & $128-256$ \\
\hline TB & 1.14 & $\mathrm{mg} / \mathrm{dl}$ & $0.00-1.50$ \\
\hline DB & 0.12 & $\mathrm{mg} / \mathrm{dl}$ & $0.00-0.60$ \\
\hline BUN & 15.3 & $\mathrm{mg} / \mathrm{dl}$ & $8.0-22.0$ \\
\hline Crea & 0.72 & $\mathrm{mg} / \mathrm{dl}$ & $0.60-1.10$ \\
\hline $\mathrm{Na}$ & 139 & $\mathrm{mEq} / \mathrm{l}$ & $138-146$ \\
\hline K & 4.0 & $\mathrm{mEq} / \mathrm{l}$ & $3.6-4.9$ \\
\hline $\mathrm{Cl}$ & 104 & $\mathrm{mEq} / \mathrm{l}$ & 99-109 \\
\hline $\mathrm{Fe}$ & $\underline{190}$ & $\mu \mathrm{g} / \mathrm{dl}$ & $80-170$ \\
\hline UIBC & $\underline{68}$ & $\mu \mathrm{g} / \mathrm{dl}$ & $180-274$ \\
\hline Ferritin & 167.7 & $\mathrm{ng} / \mathrm{ml}$ & $23.0-183.0$ \\
\hline CRP & 0.04 & $\mathrm{mg} / \mathrm{dl}$ & $0.00-0.40$ \\
\hline $\operatorname{Ig} \mathrm{A}$ & 225 & $\mathrm{mg} / \mathrm{dl}$ & $103-409$ \\
\hline $\operatorname{IgM}$ & 65 & $\mathrm{mg} / \mathrm{dl}$ & $40-221$ \\
\hline IgG & $\underline{1856}$ & $\mathrm{mg} / \mathrm{dl}$ & $918-1742$ \\
\hline $\mathrm{FT}_{4}$ & 1.24 & ng/dl & $0.88-1.56$ \\
\hline $\mathrm{TSH}$ & 2.970 & $\mu \mathrm{IU} / \mathrm{ml}$ & $0.210-3.850$ \\
\hline AFP (L3) & 3.3 & $\mathrm{ng} / \mathrm{dl}$ & $0.0-8.7$ \\
\hline $\mathrm{HbA1c}$ & 5.1 & $\%$ & $4.3-5.8$ \\
\hline $\mathrm{HBsAg}$ & Negative & & \\
\hline Anti-HBc & Negative & & \\
\hline Anti-HCV & $\underline{\text { Positive }}$ & & \\
\hline HCV RNA level & $\underline{2400}$ & $\mathrm{KIU} / \mathrm{ml}$ & \\
\hline HCV genotype & $\underline{1 b}$ & & \\
\hline
\end{tabular}

June 14, 2005.

cated by the following laboratory values from a test taken on May 16, 2006: TSH, $0.007 \mu \mathrm{IU} / \mathrm{ml}$ (normal value 0.21-3.85); $\mathrm{FT}_{3}, 4.6 \mathrm{pg} / \mathrm{ml}$ (normal value 1.9-3.5); $\mathrm{FT}_{4}, 1.58 \mathrm{ng}$ dl (normal value $0.88-1.56$ ); positive thyroid peroxidase antibodies (TPOAb), $92.2 \mathrm{IU} / \mathrm{ml}$ (normal value $<5$ ); thyroglobulin 
Table II. Laboratory data of patient with hepatitis C virus infection at time of admission for Graves' ophthalmopathy.

\begin{tabular}{|c|c|c|c|}
\hline Laboratory assay & Value & Unit & Standard value \\
\hline $\mathrm{RBC}$ & $\underline{376}$ & $\mathrm{x} 10^{4} / \mathrm{mm}^{3}$ & $430-570$ \\
\hline $\mathrm{Hb}$ & $\underline{11.9}$ & $\mathrm{~g} / \mathrm{dl}$ & $14.0-18.0$ \\
\hline $\mathrm{Ht}$ & $\underline{35.8}$ & $\%$ & $40.0-52.0$ \\
\hline WBC & 43 & $\mathrm{x} 10^{4} / \mathrm{mm}^{3}$ & $40-90$ \\
\hline Plt & 18.3 & $\mathrm{x} 10^{4} / \mathrm{mm}^{3}$ & $13.0-36.0$ \\
\hline AST & 12 & $\mathrm{U} / 1$ & $13-33$ \\
\hline ALT & 9 & $\mathrm{U} / 1$ & $8-42$ \\
\hline LDH & 122 & $\mathrm{U} / 1$ & $119-229$ \\
\hline ALP & 233 & $\mathrm{U} / 1$ & $115-359$ \\
\hline$\gamma$-GTP & 17 & $\mathrm{U} / 1$ & $10-47$ \\
\hline $\mathrm{TP}$ & 7.47 & $\mathrm{~g} / \mathrm{dl}$ & $6.70-8.30$ \\
\hline Alb & $\underline{3.94}$ & $\mathrm{~g} / \mathrm{dl}$ & $4.00-5.00$ \\
\hline $\mathrm{ChE}$ & 135 & IU/1 & $107-233$ \\
\hline $\mathrm{TC}$ & $\underline{117}$ & $\mathrm{mg} / \mathrm{dl}$ & $128-256$ \\
\hline TB & 0.43 & $\mathrm{mg} / \mathrm{dl}$ & $0.00-1.50$ \\
\hline DB & 0.06 & $\mathrm{mg} / \mathrm{dl}$ & $0.00-0.60$ \\
\hline BUN & 13.1 & $\mathrm{mg} / \mathrm{dl}$ & $8.0-22.0$ \\
\hline Crea & 0.69 & $\mathrm{mg} / \mathrm{dl}$ & $0.60-1.10$ \\
\hline $\mathrm{Na}$ & 141 & $\mathrm{mEq} / \mathrm{l}$ & $138-146$ \\
\hline $\mathrm{K}$ & 4.1 & $\mathrm{mEq} / \mathrm{l}$ & $3.6-4.9$ \\
\hline $\mathrm{Cl}$ & 104 & $\mathrm{mEq} / \mathrm{l}$ & $99-109$ \\
\hline CRP & 0.88 & $\mathrm{mg} / \mathrm{dl}$ & $0.00-0.40$ \\
\hline Glucose & 107 & $\mathrm{mg} / \mathrm{dl}$ & 80-109 \\
\hline HbA1c & 4.4 & $\%$ & $4.3-5.8$ \\
\hline CEA & 1.1 & $\mathrm{ng} / \mathrm{dl}$ & $0.0-5.0$ \\
\hline $\mathrm{SCC}$ & LT1.0 & $\mathrm{ng} / \mathrm{dl}$ & $0.0-1.5$ \\
\hline $\mathrm{FT}_{3}$ & $\underline{4.6}$ & $\mathrm{mg} / \mathrm{dl}$ & $1.9-3.5$ \\
\hline $\mathrm{FT}_{4}$ & $\underline{1.58}$ & $\mathrm{ng} / \mathrm{dl}$ & $0.88-1.56$ \\
\hline TSH & $\underline{0.007}$ & $\mu \mathrm{IU} / \mathrm{ml}$ & $0.210-3.850$ \\
\hline $\mathrm{TgAb}$ & 8.5 & IU/ml & $0.0-9.0$ \\
\hline TPOAb & 92.2 & $\mathrm{IU} / \mathrm{ml}$ & $0.0-5.0$ \\
\hline TRAb & $\underline{19.7}$ & $\%$ & $<15$ \\
\hline TSAb & 139 & $\%$ & $<180$ \\
\hline hTRAb & $\underline{7.0}$ & IU/1 & $<1.0$ \\
\hline $\mathrm{RA}$ & $<15$ & $\mathrm{IU} / \mathrm{ml}$ & $0-30$ \\
\hline ANA & Negative & & \\
\hline Anti-SS-A & Negative & & \\
\hline Anti-SS-B & Negative & & \\
\hline HCV RNA & Negative & & \\
\hline
\end{tabular}

May 16, 2006.

antibodies $(\mathrm{TgAb}), 8.5 \mathrm{IU} / \mathrm{ml}$ (normal value <9). Anti-TSH receptor antibodies [TSH receptor antibody (TRAb), 19.7\% (normal value $<15$ ); thyroid stimulating antibody (TSAb), $139 \%$ (normal value <180); human TSH receptor antibody

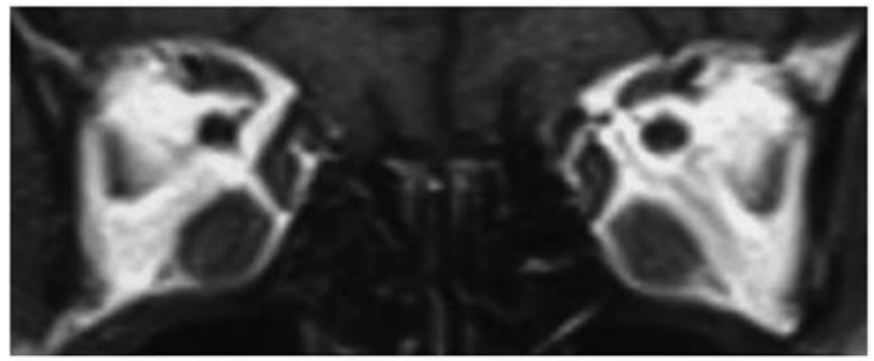

\section{T1 weighted image}

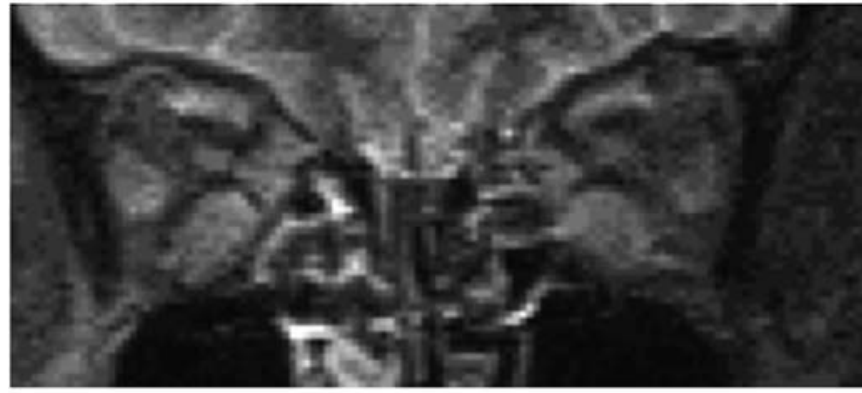

\section{STIR image}

Figure 1. MRI of the orbits shows conspicuous enlargement of the bilateral inferior rectus muscles before steroid pulse therapy (coronal view).

(hTRAb), $7.0 \mathrm{IU} / 1$ (normal value <1.0)] were positive. He had bilateral ocular disorders of supraduction and abduction, with bilateral conjunctival injection and periorbital edema. There was no tachycardia or exophthalmos (right, $12 \mathrm{~mm}$; left, $12 \mathrm{~mm}$ ). The size of the thyroid was normal according to ultrasonography. He was diagnosed with Graves' disease with ophthalmopathy by an endocrinologist. Table II shows laboratory data upon admission for Graves' ophthalmopathy, which was classified as IIa, IVc using the American Thyroid Association classification system for orbital changes in Graves ophthalmopathy (23), with a clinical activity score of 3 (24). MRI of the orbits showed conspicuous enlargement of the bilateral inferior rectus muscles (Fig. 1). As these manifestations were regarded as a severe adverse event of Peg-IFN plus RBV therapy, the combined therapy was discontinued on May 2, 2006.

Thiamazole (Mercazole ${ }^{\circledR}$; Chugai Pharmaceutical Co., Ltd., Tokyo, Japan) (15 mg/day), an anti-thyroid drug, was administered as of May 19, 2006. After 4 weeks, the thyroid functions of the patient had normalized, but his ocular symptoms persisted. Consequently, methylprednisolone sodium succinate (Solu-Medrol ${ }^{\circledR}$; Pfizer Inc., Tokyo, Japan) (1000 mg/day for 3 successive days, 3 courses) was started on July 11, 2006 as a steroid pulse therapy. Thiamazole dosage was reduced and terminated on August 12, 2006. The treatment was followed by oral prednisolone (Predonine ${ }^{\circledR}$; Shionogi \& Co., Ltd., Osaka, Japan) (20 mg daily) as of August 4, which was discontinued on October 15, 2006. Thyroid function improved and orbital edema and conjunctival injection were no longer apparent, but the double vision remained. The patient underwent extraocular muscle surgery on November 25, 2006. Fig. 2 illustrates the clinical course of the patient. 


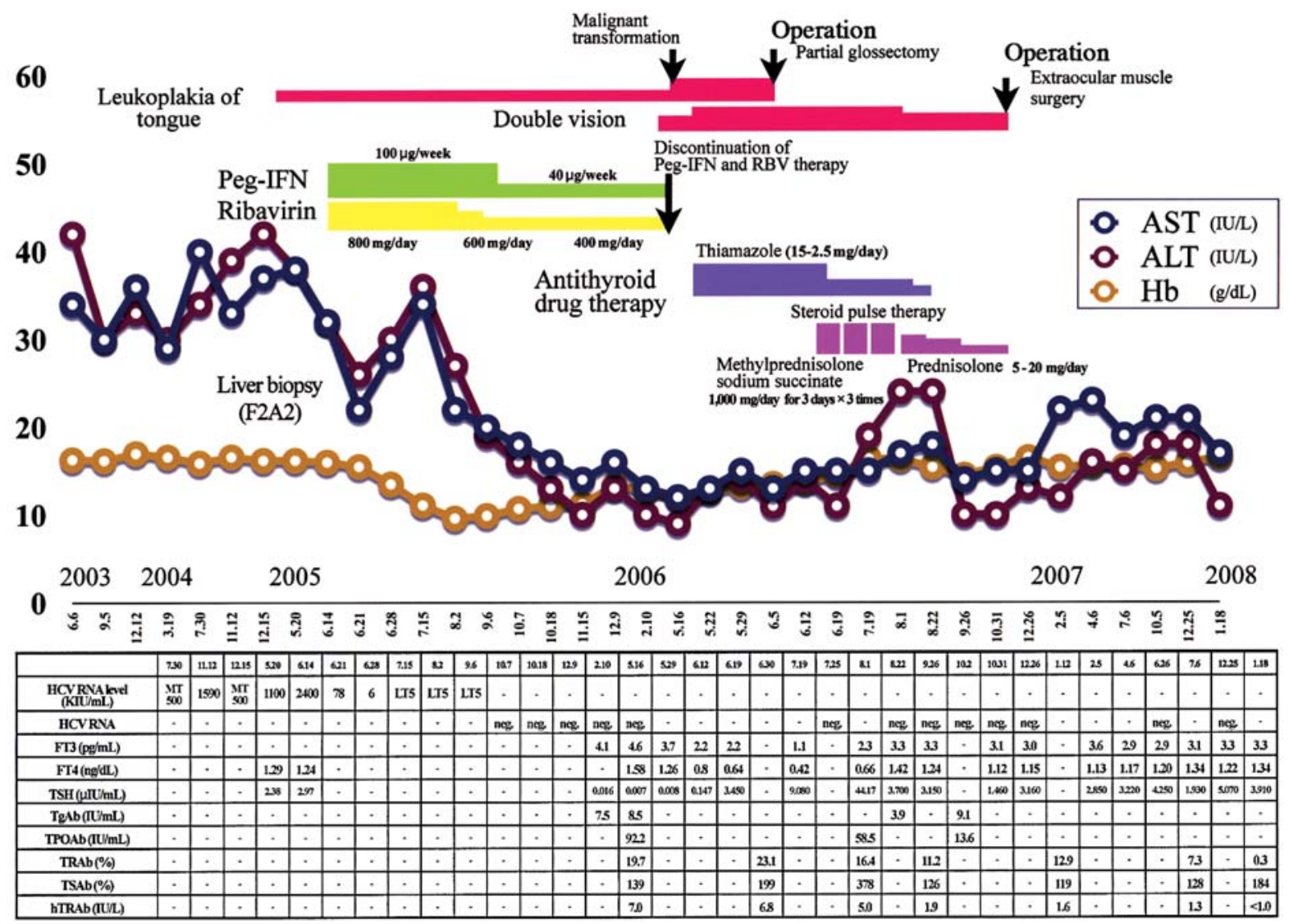

Figure 2. Clinical course of the patient.

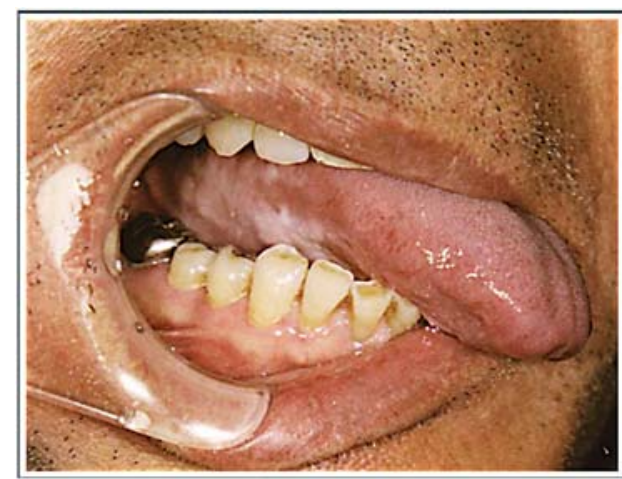

June 21, 2005

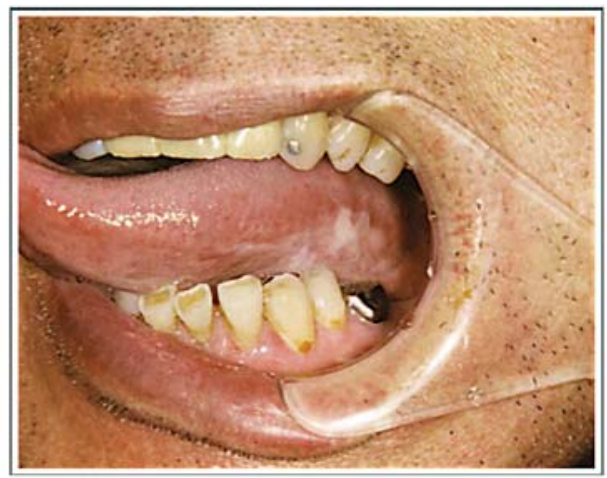

June 21, 2005

Figure 3. Bilateral oral leukoplakia of the tongue.

A

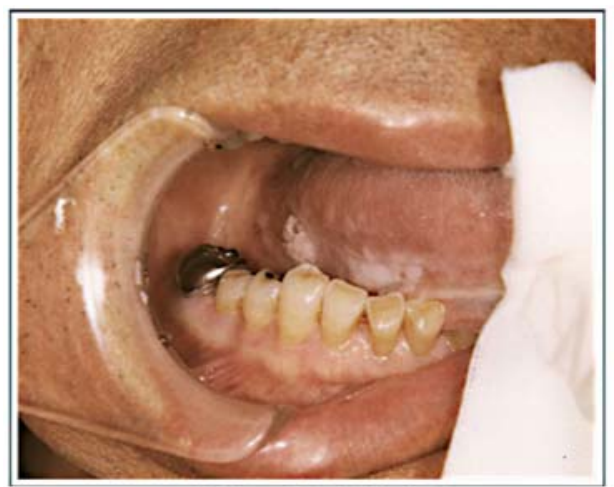

May 10, 2006
B

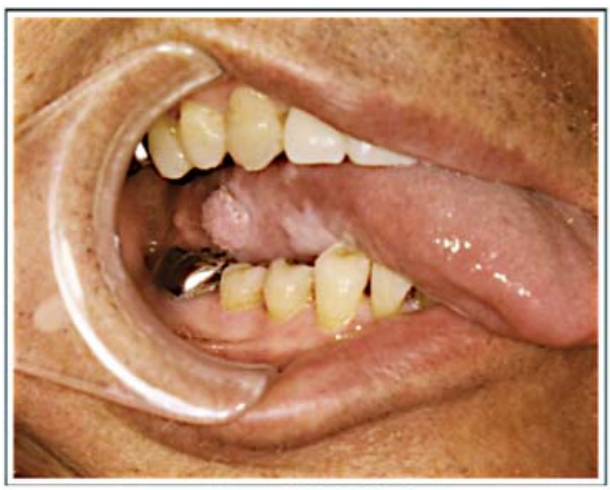

May 23, 2006

Figure 4. (A) Squamous cell carcinoma on the right lateral surface transformed from leukoplakia. (B) The mass exhibited a tendency for enhancement. 
Table III. Cases of Graves' ophthalmopathy associated with IFN treatment for hepatitis C.

\begin{tabular}{llcll}
\hline Year & Language & Refs. & Patient & Course \\
\hline 2000 & French & 33 & $62 /$ man & Development of ophthalmopathy after IFN- $\alpha$ treatment \\
2002 & English & 34 & $47 /$ man & Development of ophthalmopathy after treatment with a 6 month course of IFN- $\alpha$ and RBV \\
2002 & French & 35 & $49 /$ woman & Development of ophthalmopathy after IFN- $\alpha$ treatment \\
2005 & English & 36 & $47 /$ woman & Development of ophthalmopathy after IFN- $\alpha$ and RBV treatment \\
2007 & English & 37 & 50/woman & Exacerbation of ophthalmopathy during treatment with peg-IFN- $\alpha$ and RBV \\
2008 & English & Our case & 69/man & Development of ophthalmopathy during treatment with peg-IFN- $\alpha$ and RBV \\
\hline
\end{tabular}

The patient had symmetrically-located pre-cancerous leukoplakia on both lateral surfaces of the tongue before combination therapy with Peg-IFN $\alpha$-2b plus RBV (Fig. 3). Cytodiagnosis of the tongue showed no evidence of malignancy, and the patient did not notice the lingual leukoplakia until they were discovered by us. The leukoplakia lesions remained unaltered during the combination therapy and for 20 weeks after it srarted. The patient did not have regular checkups after November 15, 2005 but, in April 2006, became aware of a mass at the right base of the tongue. Upon examination on May 9, 2006, the presence of a superficial mass on the right lateral surface of the tongue was confirmed. The mass measured $7 \mathrm{~mm} \times 8 \mathrm{~mm}$, had a granular surface and a hard-ened area, and was without pain (Fig. 4A). The Peg-IFN plus RBV therapy, which had been administered for 47 weeks, was stopped on May 2, 2006. The mass exhibited a tendency for enhancement (Fig. 4B), and there was no induration of the tumoral circumference and dysfunction. No cervical lymph node metastasis was detected. After a diagnosis of squamous cell carcinoma of the right tongue (T1N0M0, stage I), tumor resection of the tongue was performed at the Department of Otolaryngology of the Kurume University School of Medicine on June 6, 2006.

During Peg-IFN plus RBV therapy, the patient developed Graves' ophthalmopathy due to hyperthyroidism and tongue cancer resulting from oral leukoplakia. Serum HCV RNA was negative 6 months after the therapy ended, and the case was judged to be one of sustained virological response. Since that time, the patient has been monitored regularly by a hepatologist, an oral surgeon, an otolaryngologist, an endocrinologist and an ophthalmologist. To date, there has been no local recurrence of tongue cancer or late metastasis, and no double vision.

\section{Discussion}

IFN therapy for chronic HCV infection has been associated with thyroid dysfunction. The incidence of thyroid dysfunction ranges from 0.6 to $34.3 \%(25,26)$ with a mean of $6.6 \%(27)$, while in patients treated with IFN $\alpha$ and RBV combination therapy the incidence is higher (12.1\%) (28). Recent research indicates that Peg-IFN in combination with RBV does not aggravate thyroid disease in the hepatitis C population (29).

Hypothyroidism is induced more frequently than hyperthyroidism during IFN therapy (3.8 vs. 2.8\%), and females appear to be more susceptible to IFN-induced thyroid disorders than males ( 8.2 vs. $4.8 \%$ ) (27). Factors predictive of dysthyroidism include female gender and the presence of thyroid autoantibodies before IFN treatment $(27,30)$. TPOAb is considered to be more useful than $\mathrm{TgAb}$ in monitoring immunological response in patients treated with IFN (31). Koh et al reported that the risk of developing thyroid dysfunction in thyroid antibody-positive patients appears to be $46.1 \%$, whereas only $5 \%$ of those who are thyroid antibodynegative at baseline develop thyroid dysfunction (27). They conclude that risk factors for developing thyroid dysfunction with IFN therapy are female gender, receipt of higher doses of IFN for longer durations, and the presence of thyroid autoantibodies prior to or during treatment. However, based on 138 eyes in 105 cases treated with eyelid surgery for Graves' ophthalmopathy, Inoue et al reports that the percentage of men with thyroid dysfunction increases as patients age (32).

As shown in Table III, few reported cases of Graves' ophthalmopathy have developed or been exacerbated following IFN treatment for hepatitis C (33-37). The mechanisms by which IFN induces thyroid autoimmunity remain unknown, but infectious agents have long been suspected to trigger thyroid autoimmunity, and HCV has shown the strongest association with autoimmune thyroid disease (38). HCV induces thyroid disease as an extrahepatic manifestation (9). Negativestrand HCV RNA has also been detected in the thyroid (39). IFN receptor activity results in the activation of the JAK-STAT pathway, leading to the activation of numerous IFN-stimulated genes. These effects can induce thyroid autoimmunity, and recent data have suggested that both the immune-mediated and direct thyroid-toxic effects of IFN play a role in its etiology (38). Our previous study found that the expression of thyrotropin receptor (TSH-R) mRNA in orbital fat tissue from patients with Graves' ophthalmopathy significantly correlated with orbital fat volume and the severity of ophthalmopathy (40). These results suggest that the expression of TSH-R in the orbit may play a role in the pathogenesis and clinical manifestations of ophthalmopathy.

Because the symptoms of hypothyroidism, such as fatigue, decreased appetite and depression, and the symptoms of hyperthyroidism, such as nervousness, irritability, fatigue and weight loss, can both be attributed to hepatitis C under IFN therapy, the diagnosis of thyroid disease in these patients may be delayed. This in turn may lead to the development of adverse effects induced by HCV therapy (38).

Our previous large-scale epidemiological survey showed that the incidence of oral pre-cancerous lesions and leukoplakia 
was significantly higher in patients with HCV infection (41). Oral leukoplakia are well established as one of the best examples of pre-malignancy in humans. The rate of malignant transformation of these lesions is $3-20 \%$ (42). Furthermore, our study suggests the presence and elevation of HCV RNA in oral cancer and OLP tissues (43). Multi-center studies in Japan found that the presence of anti-HCV and HCV RNA was significantly higher in patients with squamous cell carcinoma of the head and neck than in control subjects (14). It has also been demonstrated that oral cancer patients often have carcinoma of the stomach (18\%) and liver cancer (16\%) as double cancers. Double-cancer patients have significantly higher HCV infection rates than controls (44). In the present case, the patient developed malignant transformation of leukoplakia after testing negative for HCV RNA during Peg-IFN plus RBV therapy. Whether the therapy was the trigger for malignant transformation is unknown.

In conclusion, our patient had Graves' ophthalmopathy, a rare side effect of IFN therapy for hepatitis $C$, and tongue cancer during Peg-IFN plus RBV therapy. To the best of our knowledge, this is the fifth case of ophthalmopathy newlyinduced by IFN therapy (33-36). Thyroid function and preexisting thyroid autoantibodies should be closely monitored for chronic hepatitis $\mathrm{C}$ with IFN therapy. In addition, when patients with HCV infection undergo follow-up, it is important to detect extrahepatic lesions early, refer the patient to specialists and start treatment earlier as well. Finally, we emphasize that medical professionals should perform regular follow-ups, including specialized clinical examinations, on patients with $\mathrm{HCV}$ infection.

\section{References}

1. Yoshizawa H: Hepatocellular carcinoma associated with hepatitis $\mathrm{C}$ virus infection in Japan: projection to other countries in the foreseeable future. Oncology 62 (Suppl 1): 8-17, 2002.

2. Carithers RL Jr and Emerson SS: Therapy of hepatitis C: metaanalysis of interferon alfa-2b trials. Hepatology 26 (3 Suppl 1): 83-88, 1997.

3. Everson GT, Jensen DM, Craig JR, et al: Efficacy of interferon treatment for patients with chronic hepatitis C: comparison of response in cirrhotics, fibrotics, or nonfibrotics. Hepatology 30: 271-276, 1999.

4. Poynard T, Marcellin P, Lee SS, et al: Randomised trial of interferon alpha2b plus ribavirin for 48 weeks or for 24 weeks versus interferon alpha2b plus placebo for 48 weeks for treatment of chronic infection with hepatitis $\mathrm{C}$ virus. International Hepatitis Interventional Therapy Group (IHIT). Lancet 352: 1426-1432, 1998.

5. McHutchison JG, Gordon SC, Schiff ER, et al: Interferon alfa-2b alone or in combination with ribavirin as initial treatment for chronic hepatitis C. Hepatitis Interventional Therapy Group. N Engl J Med 339: 1485-1492, 1998.

6. Fried MW, Shiffman ML, Reddy KR, et al: Peginterferon alfa-2a plus ribavirin for chronic hepatitis $\mathrm{C}$ virus infection. $\mathrm{N}$ Engl $\mathrm{J}$ Med 347: 975-982, 2002.

7. Pawlotsky JM, Yahia MB, Andre C, et al: Immunological disorders in $\mathrm{C}$ virus chronic active hepatitis: a prospective case-control study. Hepatology 19: 841-848, 1994.

8. Misiani R, Bellavita P, Fenili D, et al: Hepatitis C virus infection in patients with essential mixed cryogloblinemia. Ann Intern Med 117: 573-577, 1992.

9. Huang MJ, Wu SS and Liaw YF: Thyroid abnormalities in patients with chronic viral hepatitis. Hepatology 20: 1651-1652, 1994.

10. Haddad J, Deny P, Munz-Gotheil C, et al: Lymphocytic sialadenitis of Sjögren's syndrome associated with chronic hepatitis C virus liver disease. Lancet 339: 321-323, 1992.

11. Piperno A, D'Alba R, Roffi L, et al: Hepatitis C virus infection in patients with idiopathic hemochromatosis (IH) and porphyria cutanea tarda (PCT). Arch Virol Suppl 4: 215-216, 1992.
12. Nagao $Y$, Sata M, Tanikawa K, Itoh $K$ and Kameyama T: Lichen planus and hepatitis $C$ virus in the northern Kyushu region of Japan. Eur J Clin Invest 25: 910-914, 1995.

13. Nagao Y, Sata M, Tanikawa K, Itoh K and Kameyama T: High prevalence of hepatitis $\mathrm{C}$ virus antibody and RNA in patients with oral cancer. J Oral Pathol Med 24: 354-360, 1995.

14. Nagao Y, Sata M, Itoh K, et al: High prevalence of hepatitis C virus antibody and RNA in patients with head and neck squamous cell carcinoma. Hepatol Res 7: 206-212, 1997.

15. Petit JM, Bour JB, Galland-Jos C, et al: Risk factors for diabetes mellitus and early insulin resistance in chronic hepatitis C. J Hepatol 35: 279-283, 2001.

16. Reddy KR, Wright TL, Pockros PJ, et al: Efficacy and safety of pegylated $(40-\mathrm{kd})$ interferon alpha-2a compared with interferon alpha-2a in noncirrhotic patients with chronic hepatitis C. Hepatology 33: 433-438, 2001.

17. Okanoue T, Sakamoto S, Itoh Y, et al: Side effects of high-dose interferon therapy for chronic hepatitis C. J Hepatol 25: 283-291, 1996.

18. Gatselis NK, Georgiadou SP, Tassopoulos N, et al: Impact of parietal cell autoantibodies and non-organ-specific autoantibodies on the treatment outcome of patients with hepatitis $\mathrm{C}$ virus infection: a pilot study. World J Gastroenterol 11: 482-487, 2005.

19. Carella C, Mazziotti G, Amato G, Braverman LE and Roti E: Interferon-alpha-related thyroid disease: pathophysiological, epidemiological, and clinical aspects. J Clin Endocrinol Metab 89: 3656-3661, 2004.

20. Nagao Y, Kawaguchi T, Tanaka K, Kumashiro R and Sata M: Extrahepatic manifestations and insulin resistance in an $\mathrm{HCV}$ hyperendemic area. Int J Mol Med 16: 291-296, 2005.

21. Nagao Y, Sata M, Fukuizumi K, Harada H and Kameyama T: Oral cancer and hepatitis $\mathrm{C}$ virus (HCV): can HCV alone cause oral cancer? A case report. Kurume Med J 43: 97-100, 1996.

22. Ichida F, Tsuji T, Omata M, et al: New Inuyama classification; new criteria for histological assessment of chronic hepatitis. Int Hepatol Commun 6: 112-119, 1996.

23. Werner SC: Modification of the classification of the eye changes of Graves' disease: recommendations of the Ad Hoc Committee of the American Thyroid Association. J Clin Endocrinol Metab 44: 203-204, 1977.

24. Mourits MP, Koornneef L, Wiersinga WM, Prummel MF, Berghout A and van der Gaag R: Clinical criteria for the assessment of disease activity in Graves' ophthalmopathy: a novel approach. Br J Ophthalmol 73: 639-644, 1989.

25. Fattovich G, Giustina G, Favarato S and Ruol A: A survey of adverse events in 11,241 patients with chronic viral hepatitis treated with alfa interferon. J Hepatol 24: 38-47, 1996.

26. Preziati D, La Rosa L, Covini G, et al: Autoimmunity and thyroid function in patients with chronic active hepatitis treated with recombinant interferon alpha-2a. Eur J Endocrinol 132: 587-593, 1995.

27. Koh LK, Greenspan FS and Yeo PP: Interferon-alpha induced thyroid dysfunction: three clinical presentations and a review of the literature. Thyroid 7: 891-896, 1997.

28. Bini EJ and Mehandru S: Incidence of thyroid dysfunction during interferon alfa- $2 \mathrm{~b}$ and ribavirin therapy in men with chronic hepatitis C: a prospective cohort study. Arch Intern Med 164: 2371-2376, 2004.

29. Tran HA, Attia JR, Jones TL and Batey RG: Pegylated interferonalpha2beta in combination with ribavirin does not aggravate thyroid dysfunction in comparison to regular interferon-alpha2beta in a hepatitis C population: meta-analysis. J Gastroenterol Hepatol 22: 472-476, 2007.

30. Watanabe U, Hashimoto E, Hisamitsu T, Obata H and Hayashi N: The risk factor for development of thyroid disease during interferon-alpha therapy for chronic hepatitis C. Am J Gastroenterol 89: 399-403, 1994.

31. Carella C, Amato G, Biondi B, et al: Longitudinal study of antibodies against thyroid in patients undergoing interferon-alpha therapy for HCV chronic hepatitis. Horm Res 44: 110-114, 1995.

32. Inoue $Y$, Inoue R, Kouzaki A and Koumoto N: Ophthalmic surgery on Graves' ophthalmopathy. Nippon Rinsho 64: 2291-2296, 2006.

33. Huet D, Entremont A and Hautecouverture M: Basedow's disease and interferon for hepatitis C. Recurrence as Basedow's ophthalmopathy after interferon reintroduction. Presse Med 29: $82,2000$.

34. Villanueva RB and Brau N: Graves' ophthalmopathy associated with interferon-alpha treatment for hepatitis C. Thyroid 12: 737-738, 2002. 
35. Binaghi M, Lévy C, Douvin C, Guittard M, Soubrane G and Coscas G: Severe thyroid ophthalmopathy related to interferon alpha therapy. J Fr Ophtalmol 25: 412-415, 2002.

36. Su DH, Chang YC, Liao SL and Chang TC: Lanreotide treatment in a patient with interferon-associated Graves' ophthalmopathy. Graefes Arch Clin Exp Ophthalmol 243: 269-272, 2005.

37. DeMartelaere SL, Green MK and Shore JW: Exacerbation of Graves ophthalmopathy with interferon-alpha therapy. Ophthal Plast Reconstr Surg 23: 319-321, 2007.

38. Tomer Y, Blackard JT and Akeno N: Interferon alpha treatment and thyroid dysfunction. Endocrinol Metab Clin North Am 36: 1051-1066, 2007.

39. Laskus T, Radkowski M, Wang LF, Vargas H and Rakela J: Search for hepatitis $\mathrm{C}$ virus extrahepatic replication sites in patients with acquired immunodeficiency syndrome: specific detection of negative-strand viral RNA in various tissues. Hepatology 28: 1398-1401, 1998.
40. Hiromatsu Y, Sato M, Inoue Y, et al: Localization and clinical significance of thyrotropin receptor mRNA expression in orbital fat and eye muscle tissues from patients with thyroid-associated ophthalmopathy. Thyroid 6: 553-556, 1996.

41. Nagao Y, Sata M, Fukuizumi K, Tanikawa K and Kameyama T: High incidence of oral precancerous lesions in a hyperendemic area of hepatitis C virus infection. Hepatol Res 8: 173-177, 1997. 42. Bouquot JE: Reviewing oral leukoplakia: clinical concepts. J Am Dent Assoc 122: 80-82, 1991.

43. Nagao Y, Sata M, Noguchi S, et al: Detection of hepatitis C virus RNA in oral lichen planus and oral cancer tissues. J Oral Pathol Med 29: 259-266, 2000.

44. Yoshida M, Nagao Y, Sata M, Kusukawa J and Kameyama T: Multiple primary neoplasms and HCV infection in oral cancer patients. Hepatol Res 9: 75-81, 1998. 